\title{
Effect of the Heat Curing on Strength Development of Self-compacting Mortars Containing Calcined Silt of Dams and Ground Brick Waste
}

\author{
Safi B. *, Ghernouti Y., Rabehi B., Aboutaleb D. \\ Research Unit: Materials, Processes and Environment - UR/MPE, University Boumerdes, Algeria
}

Received: November 9, 2012; Revised: February 19, 2013

\begin{abstract}
The strength development of self-compacting mortars (SCM) containing calcined silt (CS) and ground brick waste (GWB) was investigated. The variables are the nature of addition (CS and GWB) in the binder and the heat curing at different temperatures $\left(20^{\circ} \mathrm{C}\right.$ and $\left.60^{\circ} \mathrm{C}\right)$ at 7 and 14 days of curing. Two temperatures 20 and $60^{\circ} \mathrm{C}$ were applied to samples with intermediate levels (depending on the drying method applied to precast) for 18 hours in total. In this study, a Portland cement (CEMII), Calcined silt $\left(750^{\circ} \mathrm{C}\right.$ for 5 hours), ground waste brick, were used in the binders of SCM. The results show that the compressive strength to 14 days of mortars, increases with annealing $\left(60{ }^{\circ} \mathrm{C}\right)$ compared to that measured at $20^{\circ} \mathrm{C}$. Also, values of compressive strength of mortars at 14 days that are close to those obtained without 28 days curing treatment. Indeed, a strength gain of about $20.5 \%$ and $27.3 \%$ was obtained respectively for the SCM with GWB and the SCM with CS. However, a small change in mass recorded for both types of mortars.
\end{abstract}

Keywords: cement, self-compacting mortar, silt of dams, ground brick waste, compressive strength, bending strength, temperature

\section{Introduction}

Several studies have shown that the performance of concrete can be significantly improved by using selected mineral additives and, especially, some industrial by-products ${ }^{1,2}$. Granulated blast furnace slag (GBBS), fly ash (FA), and silica fume (SF) are among the most effective mineral additives used in cement or concrete because of their cementitious or pozzolanic properties ${ }^{1-6}$. However, other industrial by-products as the silt of dams and the waste brick that are also used in the formulation of mortars and concretes ${ }^{7,8}$. Recently, it was shown that the silt of dam has a pozzolanic potential which allows it be used as additive. Safi et al., ${ }^{7,9}$ showed that the introduction of $10 \%$ CS of self-compacting mortars with of $30 \%$ of GGBS $(30 \%)$ has a positive effect on the rheological behavior and the development of strength. Also, the ground waste brick (GWB) was the subject of several studies. The results obtained by Naceri et al, show that the addition of artificial pozzolan improves the setting times of the cement and the mechanical characteristics of mortar. In their work, a substitution of cement by $10 \%$ of waste brick increased mechanical strengths of mortar ${ }^{8}$. According these authors, the waste brick can be used to produce a pozzolanic cement ${ }^{9}$.

In the manufacturing field of the precast elements, companies always tried to reduce the time of preparing these elements while maintaining the quality of concrete. So, to ensure a gain of time, and significantly reducing the setting time of concrete, the parboiling (drying) process is often used for this. Due to high demand production of construction elements, the concrete industry has often resorted to use of temperature ${ }^{13,14}$. Several methods are developed and applied

*e-mail: safi_b73@umbb.dz in order to have a short period of realization and a sufficient resistance levels. A rise in temperature greatly accelerates the cement hydration reactions and affects advantageously the short term resistance. It also reduces the dormant period of hydrates and the overall structure of the hydrated cement paste is running at an advanced time. Indeed, an initial rapid rate of hydration due to higher temperatures causes a no uniform distribution of hydrated products ${ }^{16}$ cited in ${ }^{15,16}$. In the construction of large structural concrete elements where heat dissipation is slow, a significant rise in temperature within the first few days after casting due to the exothermic reaction can take place.

In order to investigate the effect of the drying temperature on the strength development of self-compacting mortars (SCMs), the mortars have been prepared with a binder mixture based of Portland cement and mineral additives (Calcined Silt (CS) and Ground Brick Waste $(\mathrm{GWB})$ ). The water-binder ratio used is keep constant (W/B $=0.45$ ) corresponding to SCMs with 28-day target mean. The physical and mechanical tests were conducted on prismatic samples $(4 \times 4 \times 16)$ of SCMs heat-treated at $60{ }^{\circ} \mathrm{C}$ for 18 hours for every age. The results of these tests were compared with those obtained at $20^{\circ} \mathrm{C}$ (room temperature).

\section{Experimental Program}

\subsection{Materials used}

The materials used in this work were Portland cement (PC) (CEM II 32.5R), calcined silt (CS) recuperated from the dam of Ferguoug (West Algeria), ground brick waste $(\mathrm{GWB})$, natural ground sand $(0 / 5 \mathrm{~mm})$ and a polycarboxylate 
based superplasticizer. The chemical composition and the physical properties of the PC, CS and GWB are given in Table 1 .

\subsection{Preparation and thermal treatment of the silt}

The silt used in this investigation was recuperated from the reject zone of the Fergoug dam (7). It was dried and crushed to a specific surface of $5000 \mathrm{~cm}^{2} / \mathrm{g}$. Then it was calcined at a temperature of $750{ }^{\circ} \mathrm{C}$ during 5 hours ${ }^{7,17}$. Generally, an optimum for kaolin clay calcinations recognized in literature is between 600 and $900{ }^{\circ} \mathrm{C}^{18,19}$.

\subsection{Mix design and proportion of self-compacting mortars}

The self-compacting mortars (SCMs) were established made using the design method of concrete equivalent mortar (CEM) developed by Schwartzentruber ${ }^{20}$. This method is based on the replacement of coarse aggregate by a mass of fine aggregate at equal specific surface. Table 2 shows the mixes details of three SCM mortars. The water-binder ratio used is keep constant $(\mathrm{W} / \mathrm{B}=0.45)$ and the fine-cement ratio is also keep constant $(\mathrm{F} / \mathrm{C}=0.10)$. The mixing process was kept constant for all mixtures.

\subsection{Conditioning and test method}

Prismatic samples $\left(40 \times 40 \times 160 \mathrm{~mm}^{3}\right)$ were manufactured for each mixture according to ASTM C192. One day after casting, a serial of samples were stored in free air under $21 \pm 1^{\circ} \mathrm{C}$ and another serial of sample were heat treated.
The maximum temperatures of curing chosen for this study, is $60^{\circ} \mathrm{C}$. It is applied on the SCMs samples studied with an intermediate stop for 18 hours according to the drying kinetics given in Figure 1. The results obtained are compared with those obtained on the same mortar but kept in a temperature controlled room at $20 \pm 1{ }^{\circ} \mathrm{C}$. The curing process is directed by a heat treatment method. The first mode is to increase the temperature of 20 to $60{ }^{\circ} \mathrm{C}$ (with curing cycle intermediate bearings) and then reduced in the same manner. The second mode is to increase and then decrease the temperature in successive stages (ripening cycle with intermediate bearings). The total time of application temperature is 18 hours. The application of temperature involves three steps: a preheating step of 2 hours, increasing the temperature to the desired value (about 3 to $4 \mathrm{~h}$ ), maintaining a constant intermediate temperature or isothermal period (about 16h), maintaining the temperature at the maximum value during the night. The cooling is effected in the same way that the rise.

After each treatment, various tests and measurements were carried on mortars studied out in order to study physical properties (flow test, weight loss, bulk density), and mechanical properties (bending strength and uniaxial compression), at different ages (3, 7, 14, 21 and 28 days). The mechanical strengths were determined on specimens heat treated assigns (figure) and another that not heat treated and that in order to see the influence of heat treatment (drying temperature) on the mechanical characteristics of SCMs.

The flow test of all SCMs were tested for flowability immediately after mixing, a few minutes later using a

Table 1. Characteristics of cementitious materials.

\begin{tabular}{lccc}
\hline & Cement & Calcined Silt (CS) & Ground Brick Waste (GWB) \\
\hline $\mathrm{SiO}_{2}$ & 21.1 & 39.71 & 31.68 \\
$\mathrm{Al}_{2} \mathrm{O}_{3}$ & 4.2 & 13.71 & 9.96 \\
$\mathrm{Fe}_{2} \mathrm{O}_{3}$ & 5.32 & 4.70 & 4.97 \\
$\mathrm{CaO}$ & 61.8 & 23.76 & 12.90 \\
$\mathrm{MgO}$ & 2.3 & 3.62 & 4.54 \\
$\mathrm{SO}$ & 2.0 & 0.42 & 2.43 \\
$\mathrm{~K}_{2} \mathrm{O}+\mathrm{Na}_{2} \mathrm{O}$ & 0.6 & 2.20 & 2.13 \\
$\mathrm{C}_{3} \mathrm{~S}$ & 58.12 & - & - \\
$\mathrm{C}_{2} \mathrm{~S}$ & 18.01 & - & - \\
$\mathrm{C}_{3} \mathrm{~A}$ & 05.62 & - & - \\
$\mathrm{C}_{4} \mathrm{AF}$ & 13.06 & - & - \\
$\mathrm{Specific}$ gravity $(\mathrm{g} / \mathrm{cm})$ & 3.10 & 2.66 & 2.64 \\
Specific surface $\left(\mathrm{m}^{2} / \mathrm{kg}\right)$ & 342 & 800 & 450 \\
\hline
\end{tabular}

Table 2. Details of mixes.

\begin{tabular}{lccc}
\hline & SCM $(\mathbf{R}) *$ & SCM $(\mathbf{C S}) *$ & SCM $(\mathbf{G W B}) *$ \\
\hline Cement $\left(\mathrm{Kg} / \mathrm{m}^{3}\right)$ & 558 & 558 & 558 \\
Mineral addition $\left(\mathrm{Kg} / \mathrm{m}^{3}\right)$ & 55.8 & 55.8 & 55.8 \\
Sand $\left(\mathrm{Kg} / \mathrm{m}^{3}\right)$ & 1349 & 1349 & 1349 \\
Water $\left(\mathrm{Kg} / \mathrm{m}^{3}\right)$ & 276 & 276 & 276 \\
Superplasticizer $(\mathrm{SP})\left(\mathrm{Kg} / \mathrm{m}^{3}\right)$ & 9.20 & 9.20 & 9.20 \\
Fine/Cement & 0.10 & 0.10 & 0.10 \\
W/B (Water/Binder) & 0.45 & 0.45 & 0.45 \\
\hline
\end{tabular}

*SCM(R): Mortar control; SCM(CS): Mortar with calcined silt; SCM(GWB): Mortar with ground brick waste. 
mini-cone with a top diameter of $70 \mathrm{~mm}$, a $100-\mathrm{mm}$ bottom diameter and a height of $60 \mathrm{~mm}^{21}$.

Three-point bending test and uniaxial compression are carried out at 1, 7, 14 and 28 days on water stored samples (see Figure 2). Three-point bending tests were carried out using a classical machine, with a capacity of $150 \mathrm{kN}$, on prismatic samples $\left(40 \times 40 \times 160 \mathrm{~mm}^{3}\right)$ according the European Standard EN 196-1. Three specimens were tested for each mix proportions. After test of flexural strength, the prism halves (six prism halves) are tested in compression by using a hydraulic press with a capacity of $3000 \mathrm{kN}$, according also the European Standard EN 196-1. Average flexural strength values were obtained on three specimens of mortar and average compressive strength values were obtained on six specimens of mortar (the more remote of strength value, is removed of the test).

\section{Results and Discussion}

\subsection{Fluidity of mortars}

Test results fluidity of mortars obtained by mini-cone test, are shown in the Figure 3. All mortars either with or without addition, have a spread that varies between 25 and $29 \mathrm{~cm}$ corresponding to the self-compacting concrete, therefore SCM mortars have a good filing capacity.

The results show that the mortar has a low fluidity SCM(CS) compared to other mortars while the fluidity of the $\operatorname{SCM}(\mathrm{GWB})$ mortar increased slightly compared to that of reference $\mathrm{SCM}(\mathrm{R})$ mortar. This is explained by the calcined silt which has a higher surface area and higher porosity than the ground brick waste. This silt absorbs more water with

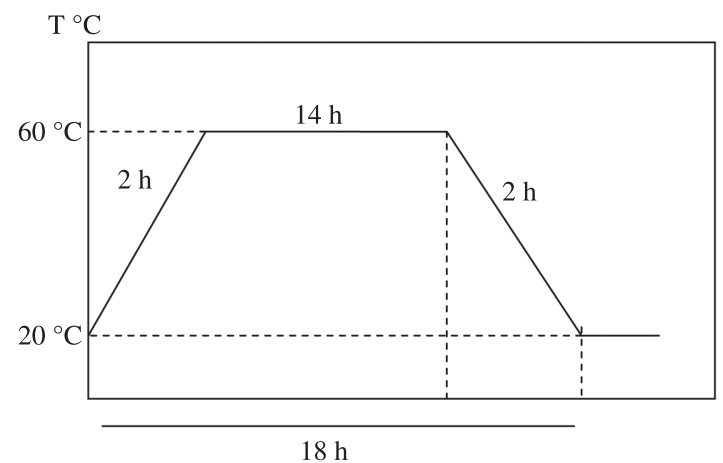

Figure 1. The heat treatment method of mortars (drying kinetics). respect to the grains of GWB which have spherical form. The result shows that GWB has improved fluidity. It has been shown that the calcined silt absorbs more water than the granulated $\operatorname{slag}^{7}$. Figure 4 clearly shows the difference of the fluidity of studied mortars.

\subsection{Bulk density of mortars $M B A P$}

The results of density measured of the SCMs mortars studied are shown in Figure 5. The density is relatively high for the mortars with additions from the mortar than without the addition, which explains the filling role of the cementitious matrix played by those additions (see Figure 5). Indeed, they have a high specific surface and are also added in addition to the concrete matrix, fit into the gaps, they thicken the skeleton of concrete and therefore it results in an increase in density and a vacuum decrease.

\subsection{Mechanical resistance of self-compacting mortars}

The mechanical test results on mortars studied are given in Figures 6 and 7. The figures present respectively the bending strength and compressive strength of SCMs mortars with and without heat treatment.

An increase of the bending and compressive strength as function of age (3, 7, 14, 21 and 28 days) was observed for all mortars. That is the phenomenon of hydration of cement which causes the evolution of compactness with curing time. Indeed, the hydration of the components of cement $\mathrm{C}_{3} \mathrm{~S}$ and $\mathrm{C}_{2} \mathrm{~S}$ give birth of the calcium silicate hydrate (CSH) which increase resistance. It is noted that, at 28 days the reference mortar presents resistance values slightly lower

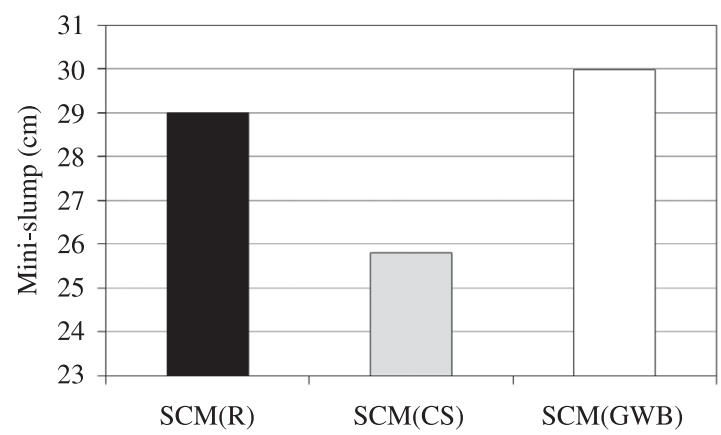

Figure 3. Mini-slump for SCM mortars studied.
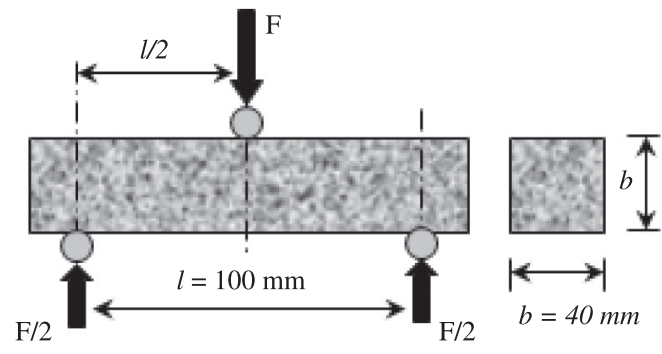

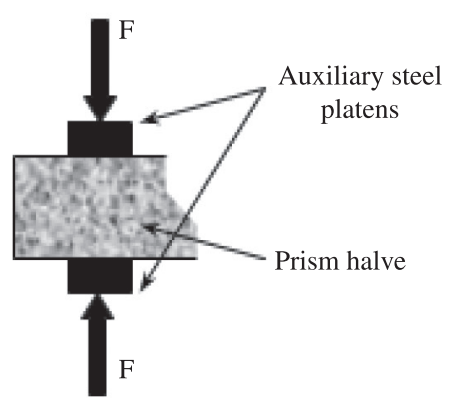

Figure 2. Three-point bending test and uniaxial compression. 
comparatively with those of the SCM(CS) and SCM(GWB) mortars (Figure 6b, c). This difference is due mainly to the pozzolanic property of the additions having an amorphous structure or partially which in the presence of $\mathrm{Ca}(\mathrm{OH})_{2}$ released during the hydration of cement and water, gives birth new products (CSH and $\mathrm{CAH}$ ), having same properties similar to those formed containing minerals of cement ${ }^{11,22}$.

\subsection{Development of relative strength on compressive of SCMs mortars}

The results obtained show that mortars which have undergone heat treatment (Figure 8), exhibit a better

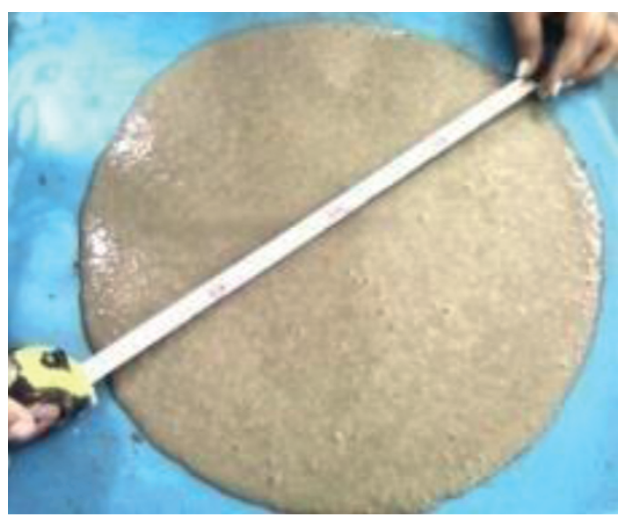

(a)

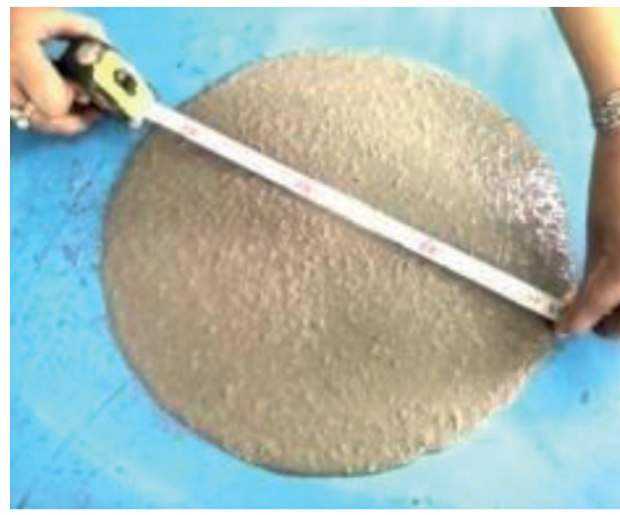

(b)

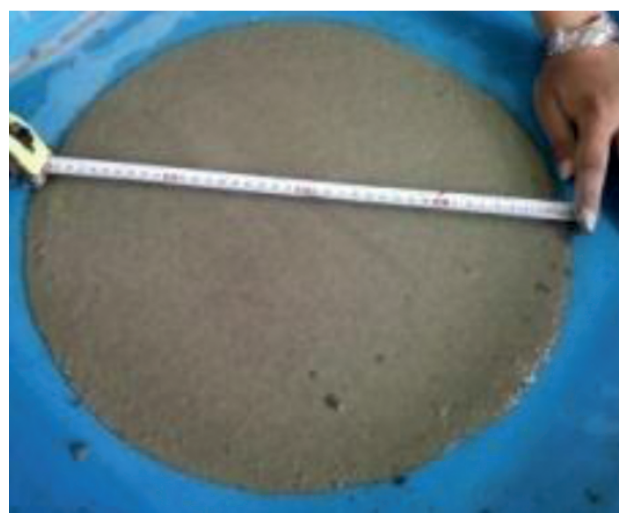

(c)

Figure 4. The mortars fluidity; (a) $\operatorname{SCM}(\mathrm{R})$ (b) $\mathrm{SCM}(\mathrm{CS})$ (c) $\operatorname{SCM}(\mathrm{GWB})$. compressive strength as a function of age $(3,7,14,21$ and 28 days), compared to those without treatment, which is probably due the effect of temperature, which accelerates the hydration reactions. As an example, gains of compressive strength at 28 days were obtained in order of $27 \%$ and

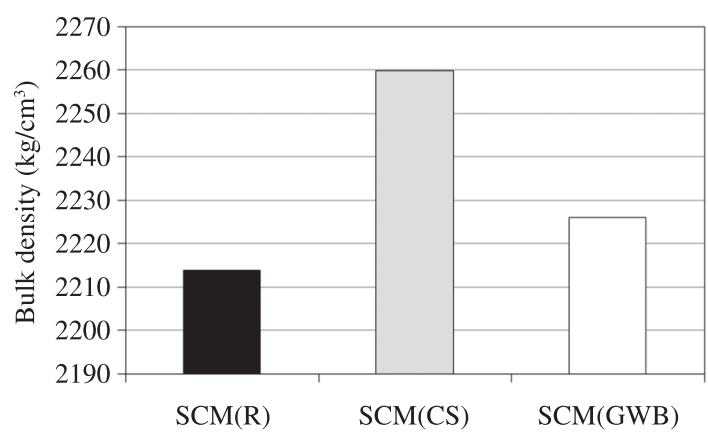

Figure 5. The bulk density of SCM mortars studied.

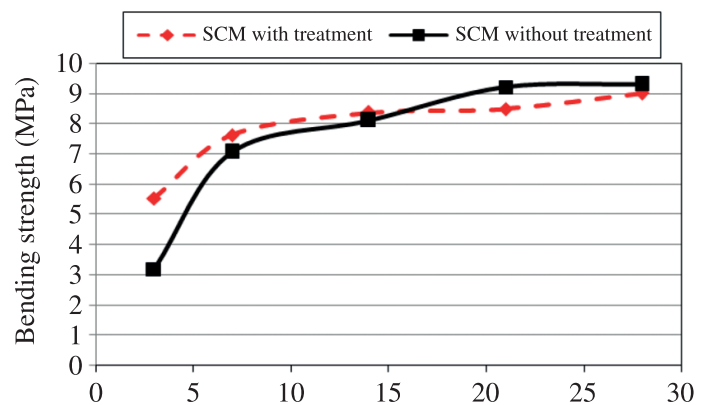

(a)

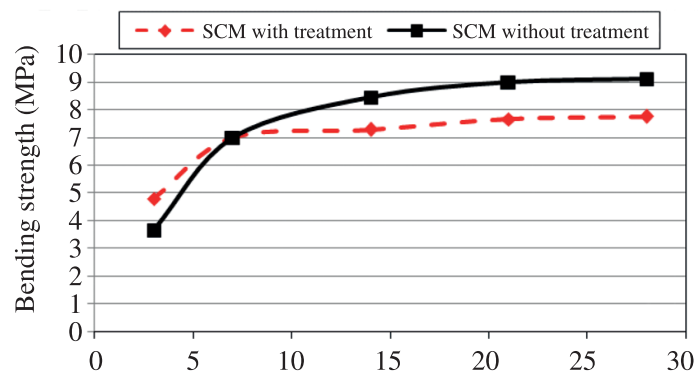

(b)

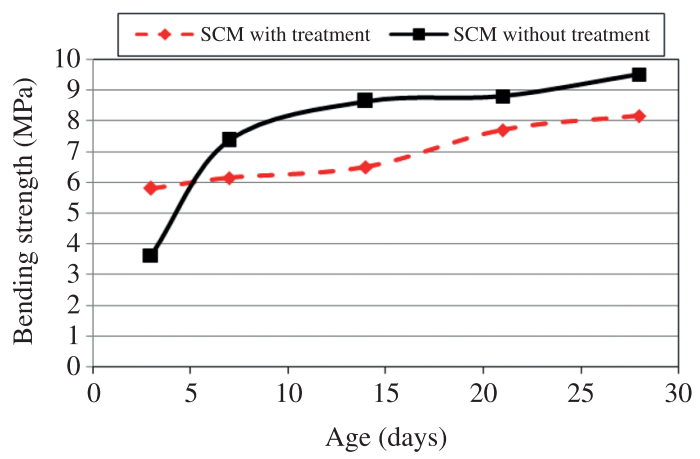

(c)

Figure 6. The bending Strength evolution of the SCMs mortars respectively with and without heat treatment as a function age; (a) $\operatorname{SCM}(\mathrm{R})$ (b) $\mathrm{SCM}(\mathrm{CS})$ (c) $\mathrm{SCM}(\mathrm{GWB})$. 
$22.5 \%$ respectively for $\mathrm{SCM}(\mathrm{GWB})$ and $\mathrm{SCM}(\mathrm{CS})$ treated mortars at $60^{\circ} \mathrm{C}$

The GWB and CS have a high fineness, and its specific weight is lower than that of the cement, both of which increased the amounts of consistency water in relation with the GWB and CS addition (Figure 8b, c).

For the mortars flexural strength which have undergone treatment, continuous improvement was observed compared to mortars up to 14 days without treatment, or it was found the opposite effect, this can be explained by the fragility of specimens from this age processing and ripening (Figure 7a-c).

According to these figures, the strength values at 14 days, obtained for all mortar compositions having undergone thermal treatment, are almost similar or sometimes better than those obtained by non-heat treated

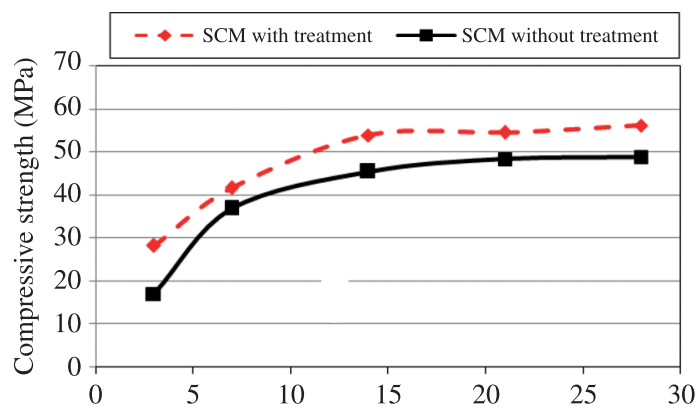

(a)

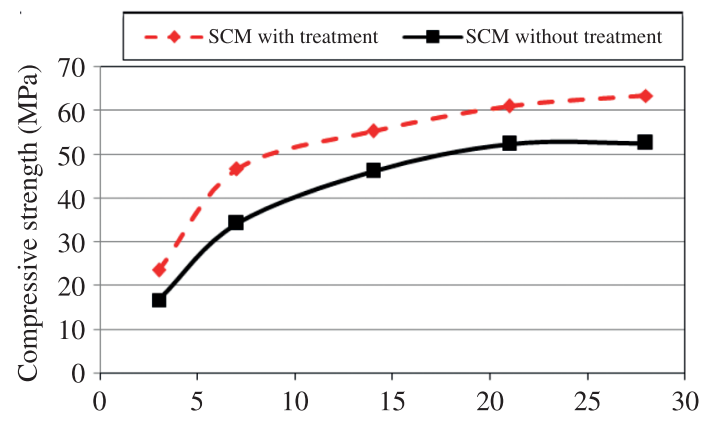

(b)

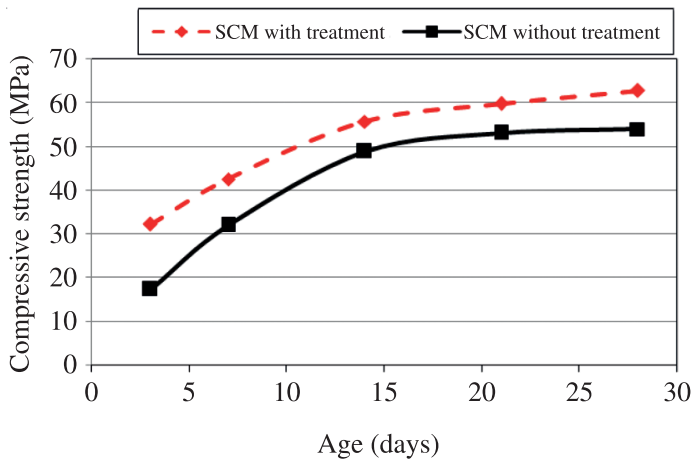

(c)

Figure 7. Evolution of the compressive strength of the SCMs mortars respectively with and without heat treatment as a function age; (a) $\operatorname{SCM}(\mathrm{R})$ (b) $\mathrm{SCM}(\mathrm{CS})$ (c) $\mathrm{SCM}(\mathrm{GWB})$. mortars at 28 days (Figure 8). Which is advantageous from the point of views took work, stripping before 28 days for precast elements.

\subsection{Gain of compressive strength of SCMs mortars}

An improvement in the compressive strengths was possible for all mortars (SCM(R), SCM(CS), SCM(GWB)), under effect of heat treatment (Figure 9). Yet, comparatively to the mortar at 28 days $\left(20{ }^{\circ} \mathrm{C}\right)$, an improvement in the compressive strengths is $5 \mathrm{MPa}$ for the control mortar $(\mathrm{SCM}(\mathrm{R})), 3 \mathrm{MPa}$ for the $\mathrm{SCM}(\mathrm{CS})$ mortar and $1 \mathrm{MPa}$ for the $\operatorname{SCM}(\mathrm{GWB})$ mortar.

Comparatively to all the hardening age, the heat treatment improved the compressive strength of mortars. Indeed, at 3 days the strength gain was $67 \%, 40 \%$ and $85 \%$ respectively for $\mathrm{SCM}(\mathrm{R}), \mathrm{SCM}(\mathrm{CS})$ and $\mathrm{SCM}(\mathrm{GWB})$

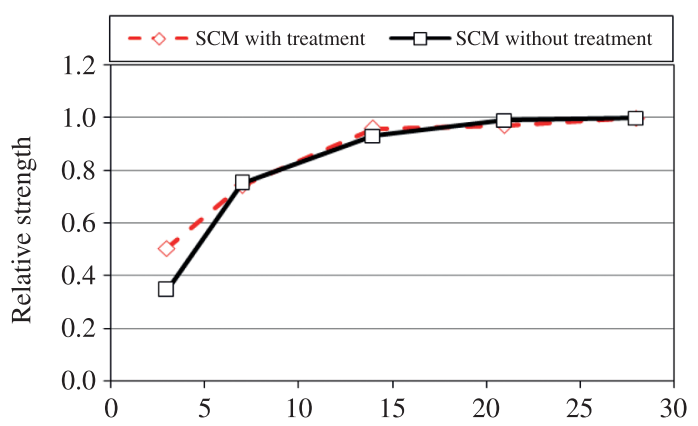

(a)

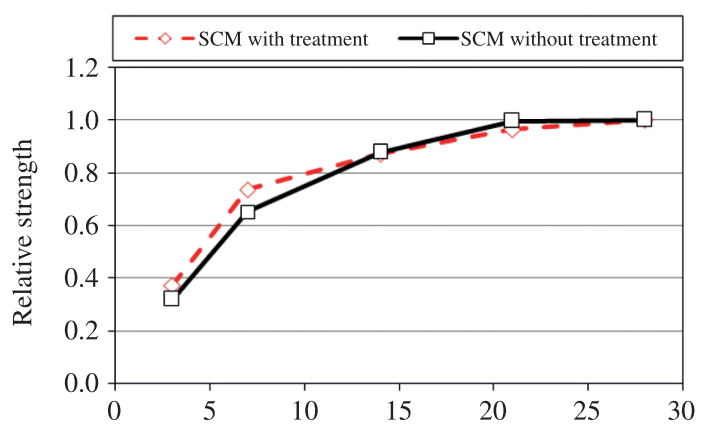

(b)

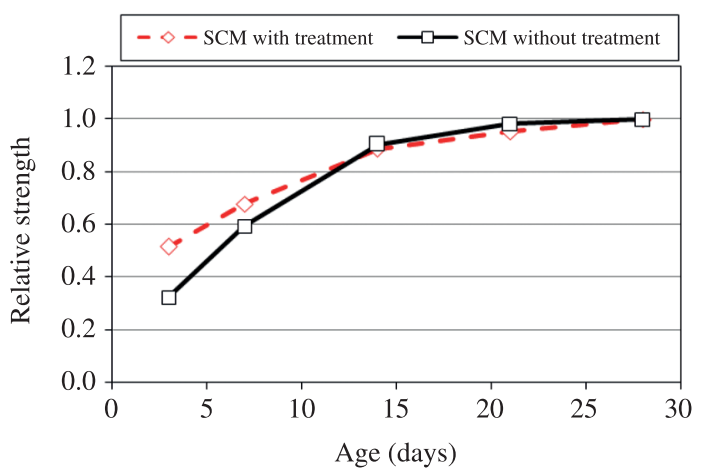

(c)

Figure 8. Development of relative strength on compressive of selfcompacting mortars (a) $\mathrm{SCM}(\mathrm{R})$ (b) $\mathrm{SCM}(\mathrm{CS})$ (c) $\mathrm{SCM}(\mathrm{GWB})$. 


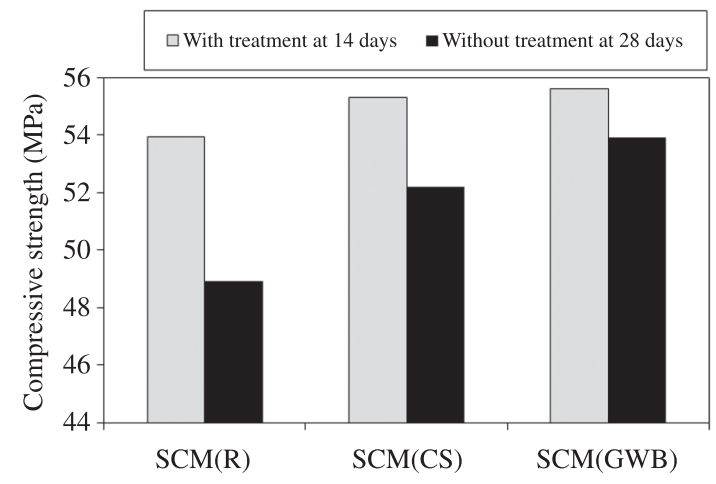

Figure 9. Comparison of treated and untreated mortars thermally; compressive strength of the SCMs mortars at 14 and 28 days.

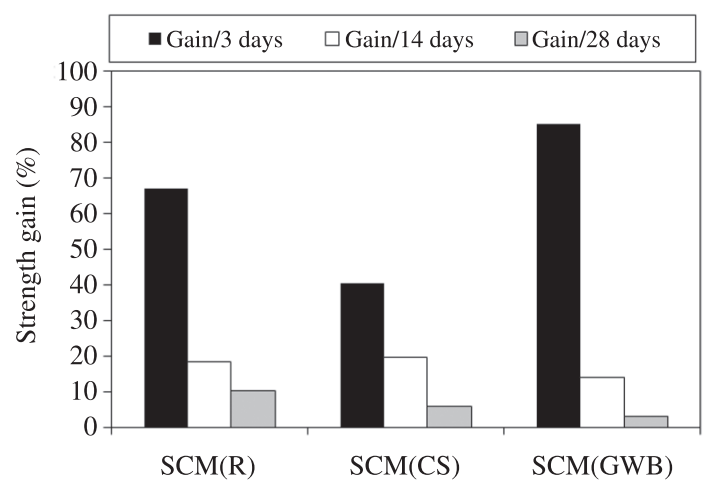

Figure 10. Gain compressive strength of the SCMs mortars.

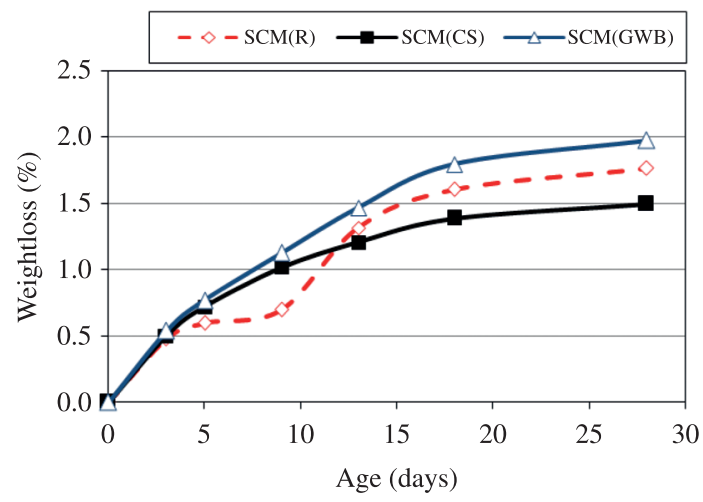

Figure 11. Evolution of weight loss of the SCMs mortars as function age.

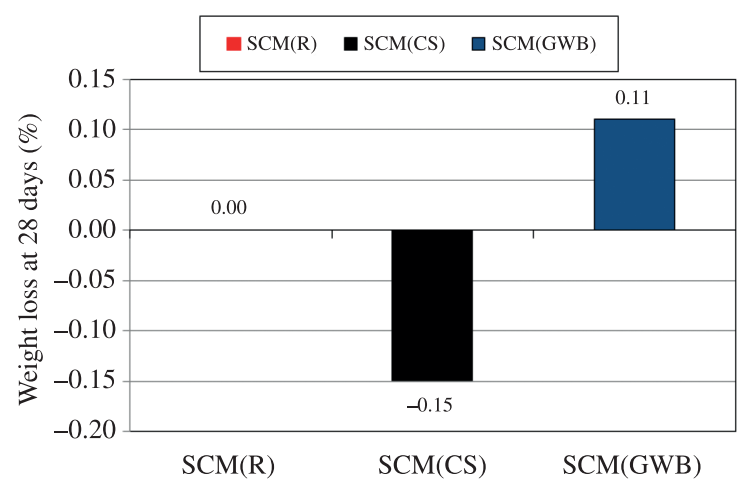

Figure 12. The weight loss of the SCMs mortars at 28 days. mortars (Figure 10). This is explained by the rise in temperature which greatly accelerates the cement hydration reactions at 3 days and affects advantageously the short term resistance ${ }^{15,22}$.

\subsection{Weight loss of the SCMs mortars studied}

The results of the weight loss of the mortars studied during 28 days of hardening are represented in Figure 11 and 12. Increase continues of the weight loss of the various mortars according to the age, were recorded. However, the $\mathrm{SCM}(\mathrm{CS})$ mortar has a weight saving compared to the control mortar and continues to increase. This increase is due to the reaction of cement hydration at short-time (before 14 days). Indeed, the weight saving of the mortars samples with additions is almost similar to the reference mortar without additions that is due to the positive effect of the mineral additions from point of a swelling view ${ }^{3,7}$.

\section{Conclusion}

The objective of this study was to evaluate the physical-mechanical behavior of self compacting concrete mortar-based calcined silt (CS) and ground brick waste (GWB), under the temperature effect. In order to study the performance of self compacting mortars (Concrete equivalent mortar) under the drying temperature effect applied currently for the prefabricated elements in building. The results obtained in this study, show clearly that it is possible to use the Self-compacting formulations containing the calcined silt and ground brick waste from the brick product. Indeed, the results show that:

- The fluidity of self-compacting mortar (SCMs), has improved in the ground brick waste. A fluidity loss is recorded for SCMs mortars in the presence of calcined silt; it can be improved by increasing the dosage of superplasticizer;

- A weight gain is obtained using this type of addition in self-compacting concrete;

- The mechanical strength (compressive strength and bending strength) are significantly improved in the presence of the calcined silt and the ground brick waste;

- Heat treatment $\left(60{ }^{\circ} \mathrm{C}\right)$ significantly improves the mechanical performance of SCMs mortars. At 14 days, the compressive strength recorded with heat-treatment of $\mathrm{SCM}_{\mathrm{S}}$ mortars is close or same to that reference mortar $\mathrm{SCM}(\mathrm{R})$;

- A strength gain is obtained in the range $20 \%$ and $27.5 \%$ respectively for $\mathrm{SCM}(\mathrm{CS})$ and $\mathrm{SCM}(\mathrm{GWB})$ mortars with heat treatment at $60{ }^{\circ} \mathrm{C}$; and

- A weight gain is recorded about $0.11 \%$ for all SCMs mortars based waste brick from the reference mortar. By cons, mass loss is observed for those based on the calcined silt.

It would be very interesting to complete this study on formulations of self-compacting concrete (SCC), using the temperature of $60^{\circ} \mathrm{C}$ and $100{ }^{\circ} \mathrm{C}$. 


\section{References}

1. Zia P, Leming ML and Ahmad SH. High-performance concretes: A State-of-the-Art Report, SHRP-C/FR-91-103, Strategic Highway Research Program. Washington: National Research Council; 1991.

2. Sobolev K. The effect of complex admixtures on cement properties and development of a test procedure for the evaluation of high strength cements. Advanced in Cement Research. 2003; 15(2):65-75. http://dx.doi.org/10.1680/ adcr.2003.15.2.67

3. Barnett SJ, Soutsos MN, Bungey JH and Millard SG. Fast-track concrete construction using cement replacement materials. In: Proceedings of the Eighth CANMET/ACI International Conference on Fly Ash, Silica Fume, Slag, and Natural Pozzolans in Concrete; 2004; Farmington Hills. Farmington Hills: American Concrete Institute; 2004. p. 135-151. ACI SP-221.

4. American Concrete Institute - ACI. Slag cement in concrete and mortar. Farmington Hills: American Concrete Institute; 2003. Report of ACI Committee 233. ACI 233R-03.

5. Bijen J. Blast furnace slag cement for durable marine structures. Netherlands: Stichting BetonPrisma; 1996. p. 28.

6. Escalante-Garcîa JI and Sharp JH, The microstructure and mechanical properties of blended cements hydrated at various temperatures. Cement and Concrete Research. 2001; 31(5):695-702. http://dx.doi.org/10.1016/ S0008-8846(01)00471-9

7. Safi B, Benmounah A and Saidi M. Rheology and zeta potential of cement pastes containing calcined silt and ground granulated blast-furnace slag. Materiales de Construcción. 2011; 61(303):353-370. http://dx.doi. org/10.3989/mc.2011.61110

8. Naceri A and Hamina MC. Use of waste brick as a partial replacement of cement in mortar. Waste Management. 2009; 29(8):2378-84. http://dx.doi.org/10.1016/j. wasman.2009.03.026

9. Safi B. Formulation et caractérisation rhéologique et physicomécanique des pâtes cimentaires et mortiers autoplaçants. [Thesis]. University of Boumerdes-Algérie; 2012.

10. Pašalić S, Vučetić S, Zorić D, Ducman V and Ranogajec J, Pozzolanic mortars based on waste building materials for the restoration of historical buildings. Chemical Industry and Chemical Engineering Quarterly. 2012; 18(2):147-154. http:// dx.doi.org/10.2298/CICEQ110829056P
11. Wild S. Observations on the use of ground waste clay brick as a cement replacement material. Building Research and Information. 1996; 24(1):35-40. http://dx.doi. org/10.1080/09613219608727496

12. Yaprak H and Simsek O. Performance of cement mortars replaced by ground waste brick in different aggressive conditions. Ceramics - Silikáty. 2011; 55(3):268-275.

13. Edrogdu S and Kurbetci S. Optimum heat treatment cycle for cement of different type and composition. Cement and Concrete Research.1998; 28(11):1595-1604. http://dx.doi.org/10.1016/ S0008-8846(98)00134-3

14. Neville AM. Chapter 8. Temperature effects in concrete. In: Properties of concrete. Paris: Editions Eyrolles; 2000. p. 345-350.

15. Kjellsen KO. Heat curing and post curing regimes of high performance concrete: influence on microstructure and C-S-H composition. Cement and Concrete Research. 1996; 26(2):295-307. http://dx.doi.org/10.1016/0008-8846(95)00202-2

16. Verbeck GJ and Helmuth RH. Structures and physical properties of cement paste. In: Proceedings of the 5th International Symposium on the Chemistry of Cement; 1968; Tokyo. Tokyo; 1968. part II. p. 1-32.

17. Semcha A. Valorisation des sédiments de dragage: Applications dans le BTP, cas du barrage de Fergoug. UFR sciences, University of Reims- France; 2006.

18. Ambroise J, Murat M and Pera J. Investigations on synthetic binders obtained by middle-temperature thermal dissociation of clay minerals. Silicates Industries. 1986; 7(8):99-107.

19. Sayanam RA, Kalsotra AK, Mehta SK, Sing RS and Mandal G. Studies on thermal transformations and pozzolanic activities of clay from Jammu region (India). Journal of Thermal Analysis. 1989; 35:9-106. http://dx.doi.org/10.1007/ BF01914268

20. Schwartzentruber A and Catherine C. Method of the concrete equivalent mortar (CEM) - A new tool to design concrete containing admixture. Materials and Structures. 2000; 33(8):475-482. http://dx.doi.org/10.1007/ BF02480524

21. European Federation of National Associations Representing Concrete - EFNARC. Specification and guidelines for self compacting concrete. EFNARC; Feb 2002. p. 29-35. Available from: <http://www.efnarc.org >.

22. Reinhardt HW and Stegmaier MS. Influence of heat curing on the pore structure and compressive strength of self-compacting concrete (SCC). Cement and Concrete Research. 2006; 36:879-885. http:// dx.doi.org/10.1016/j.cemconres.2005.12.004 